Andrzej J. MADERA

Akademia Pedagogiczna w Krakowie

\title{
Akcja Wyborcza Solidarność - brak marketingu politycznego i medialnego jako jedna z przyczyn upadku
}

Dowstanie, funkcjonowanie i ciagłość rządzenia AWS godne są opraco-
wania i szerszej analizy. Po raz pierwszy bowiem od 1989 roku spektakularna inicjatywa jednocząca ugrupowania prawicowe zyskała swój wymiar praktyczny. Zjednoczona prawica nie tylko przejęła władzę w kraju na cztery lata, ale zdolna była do podjęcia zasadniczych reform ustrojowych. Jednak praktyka rządzenia pokazała, że politykom prawicy nie udało się wykorzystać walorów nowego ugrupowania. Tarcia, kłótnie i swary wewnątrz AWS oraz brak zdecydowanego przywództwa zaćmiły i skomplikowały tak przychylnie ocenione przez wyborców idee ${ }^{1}$. Pomimo zapowiedzi czołowych działaczy AWS oraz wszelkich szans ku temu, nie utworzono partii polskiej prawicy. Liderzy poszczególnych organizacji wchodzących w skład AWS nigdy nie wyrzekli się ambicji przywódczych. W konsekwencji doprowadziło to do „,degrengolady” całego bloku. Podziały i kolejne rejestracje nowych partii politycznych, kosztem koalicji AWS, dopełniły dzieła samozagłady. Niewątpliwym efektem błędów polityków AWS była bezprecedensowa sytuacja z 2001 roku, gdy rządząca wcześniej partia nie osiągnęła progu wyborczego do parlamentu. Akcja Wyborcza Solidarność nigdy nie wykorzystała swojego potencjału, znikając przedwcześnie z mapy politycznej. Nie powiodły się również próby reanimacji tego ugrupowania. Niekorzystny wizerunek społeczny i brak marketingu politycznego został świetnie wykorzystany przez SLD i jego satelickie ugrupowanie - UP oraz, skłonne do koalicji, PSL.

Marketing polityczny jest definiowany jako ,zespół technik wykorzystywanych dla stworzenia odpowiedniego obrazu kandydata wśród jego elektoratu, wyróżnienia go spośród rywali w celu uzyskania maksymalnej

1 P. Siennicki, Świat bez Mariana, „Nowe Państwo” 2002, nr 10. 
ilości głosów"2. Na tę polityczną ofertę, która jest towarem, składają się ideologie, programy wyborcze, personel (kadry) danego ugrupowania ${ }^{3}$. Niewatpliwą specyfiką polskiego marketingu politycznego było podejście do sondaży. W kampaniach wyborczych na Zachodzie sondaże to rzecz niemal święta; w Polsce natomiast to wciąż element gry politycznej. I tak, w przypadku Unii Polityki Realnej - sondaże potwierdzały rzeczywistość, jednak już w odniesieniu do Samoobrony nie były tak przekonywujące ${ }^{4}$. Uwarunkowania i stosowanie marketingu politycznego musza, mimo wszystko, uwzględniać kontekst historyczny, społeczny i kulturalny danego społeczeństwa.

Zjawiskiem nierozerwalnie związanym ze skutecznym sprawowaniem władzy jest propaganda ${ }^{5}$. Jest to również rodzaj pewnej aktywności, która towarzyszy działalności politycznej od zarania dziejów państwowości ${ }^{6}$. Klasyk i pionier badań nad propagandą, H. Lasswell, określił to zjawisko „tworzeniem jednolitej postawy przez manipulowanie ważnymi treściami" "7. Zamierzone manipulowanie oraz przekazywanie informacji w celu osiagnięcia politycznych celów ${ }^{8}$ jest dziś regułą postępowania partii politycznych. W Polsce ma to wymiar szczególny, ponieważ reżim komunistyczny dawał rządzącym niemalże nieograniczone możliwości w kreowaniu przekazów propagandowych. Także i dziś mamy do czynienia z próbami zawłaszczania państwa w imię partykularnych interesów politycznych. Monopol władzy przejawia się w zatrudnianiu w radach nadzorczych i zarządach radia i telewizji ludzi związanych tylko z jednym układem politycznym. To, co miało stanowić regułę interesu publicznego, przekształcono w dobrze funkcjonujące ,,przedsiębiorstwo układu poli-

2 M. Cichosz, D. Skrzypiński, Co to jest marketing polityczny, „Aida” 1997.

J. Muszyński, Marketing polityczny, WSZiA, Warszawa 1999, s. 77.

${ }^{4}$ Szczególnie jaskrawe różnice w podejściu do marketingu politycznego zauważalne były podczas kampanii parlamentarnej w 1993 r. i prezydenckiej w 1995 r. Por. A. Sułek, Sondaż polski, Warszawa 2000.

${ }^{5}$ Samo słowo propaganda wywodzi się od łacińskiego propagare, oznaczającego „krzewienie, szczepienie winorośli”.

${ }^{6}$ O. Thomson wyprowadza dzieje propagandy od czasów starożytnego Izraela, zob. idem, Historia propagandy, Warszawa 2001.

7 Ibidem, s. 10.

8 T. O'Sullivan, J. Hartley, D. Sannders, M. Montgommery, J. Fiske, Key concepts in communication and cultural studies, Rontledge, London-New York, s. 246-247, „The international control, manipulation and communication of information and imagery in order to achieve certain political objectives". 
tycznego". Wszelka komunikacja, jak i procesy decyzyjne przebiegają $\mathrm{w}$ jednym kierunku, mianowicie to centrum przekazuje informacje i wywiera nacisk na działania podległych mu jednostek ${ }^{9}$.

Warto przypomnieć o podziale propagandy na białą, szarą i czarną ${ }^{10}$. Propaganda biała charakteryzuje się tym, że adresat przekazu może rozpoznać nadawcę, który nie ukrywa się, jest znany odbiorcy. W propagandzie szarej nie ma już takiej jasności jak w propagandzie białej. Propaganda czarna ma zastosowanie w sytuacjach nadzwyczajnych (klęska żywiołowa, wojna, stany zagrożenia). Cechuje ją świadome fałszowanie wiadomości, ukrywanie źródła przekazu, wywołanie w odbiorcy przeświadczenia, że tożsamość nadawcy przekazu jest inna niż mógłby przypuszczać.

Celem propagandy jest nie tylko wpływ na umysłowość odbiorcy; jej zadaniem jest także bardziej rozciągnięte w czasie oddziaływanie na ludzi $^{11}$. Zresztą, teoria społeczeństwa masowego zakłada, że nowoczesne społeczeństwa stanowią „masę” czyli wielką zbiorowość ludzi niezdolnych do podjęcia wspólnych działań, podatną na manipulację ${ }^{12}$.

Tak więc, celem propagandy, jak i marketingu jest wywołanie u odbiorcy pewnych pożądanych przez nadawcę postaw bądź wywołanie zachowań zgodnych z zamiarem i interesem nadawcy komunikatów. Niezależnie od tego czy chodzi o marketing polityczny, czy propagandę, poczynania te dotyczą zawsze społeczeństwa - obywateli danego państwa.

Transformacje ustrojowe ${ }^{13}$, zapoczątkowane pokojowym zwycięstwem „Solidarności” w 1989 roku, przestawiły i przewartościowały cały dotychczasowy rynek prasy w Polsce. Pojawiła się potrzeba prezentowania różnych punktów widzenia, także w odniesieniu do kwestii politycznych. W Polsce sympatie polityczne i zaangażowanie dziennikarzy nadal przesądzają o nastawieniu politycznym wielu organów prasowych. Wyrazem przyjętej orientacji politycznej danego tytułu, pomimo deklarowanej bezstronności redakcji, jest ścisłe powiązanie dziennikarzy z poszczególnymi partiami politycznymi. Dotyczy to zarówno lewicy („Trybuna”), jak i prawicy (,Tygodnik Solidarność”). Za czasów ekipy Jerzego Buzka

9 S. Ossowski, O osobliwościach nauk społecznych, Warszawa 2001, s. 60.

10 B. Bobek-Ostrowska, J. Fras, B. Ociepka, Teoria i praktyka, Warszawa 2001, s. 42 .

11 G. Sartori, Teoria demokracji, Warszawa 1994, s. 123-124.

12 T. Goban-Klas, Media i komunikacja, Warszawa 1999, s. 121.

13 G. G. Kopper, Transformacja systemu medialnego $w$ Polsce, w: Media i dziennikarstwo $w$ Polsce 1989-95. 
„Tygodnik Solidarność" stał się forum informacji o działaniach rządu ${ }^{14}$. Także ,Życie" prezentowało na swych łamach prawicowo zaangażowane polemiki, choć - według redaktora naczelnego, Tomasza Wołka - gazeta była „niezależna i konserwatywna" 15 .

Jak ważne są środki masowego przekazu w procesie informowania społeczeństwa, dowodzą wyniki badań społecznych. Zgodnie z sondażem OBOP-u, na pytanie, skąd respondent czerpie informacje o tym, co robi rząd, $96 \%$ pytanych odpowiedziało, że z telewizji publicznej, $71 \%$ z Polskiego Radia, $58 \%$ - z prasy lokalnej, $54 \%$ - z prasy ogólnopolskiej, a $40 \%$ z programów telewizji komercyjnej ${ }^{16}$. Zaledwie $12 \%$ wskazało na „inne źródła”. Tak więc, celem kreowania wizerunku medialnego jest właściwa komunikacja z otoczeniem, a w pewnym zakresie również tworzenie wizerunku medialnego korzystnego dla siebie - w toku wykładni wydarzeń. W przypadku koalicji AWS-UW przeszkodę w jednolitym wizerunku medialnym stanowiła federacyjna struktura ugrupowania. Poszczególne partie wchodzące w skład AWS prowadziły już wcześniej własną politykę informacyjną oraz miały osoby odpowiedzialne za komunikowanie się z dziennikarzami. Dodatkowo korespondenci dysponowali wypowiedziami rzecznika prasowego rządu, rzecznika prasowego AWS, rzecznika prasowego NSZZ „Solidarność” oraz rzecznika prasowego klubu parlamentarnego AWS. Odbiór tych wszystkich wypowiedzi wywoływał nie tylko zamieszanie medialne, ale także wskazywał na całkowitą niespójność AWS.

Podczas przeprowadzania reform ustrojowych Centrum Prasowe Rządu wsparto dodatkowym budżetem dla celów akcji informacyjnej (ulotki, broszury, konferencje prasowe) ${ }^{17}$. Pomimo szeroko zakrojonej akcji informacyjnej, dziennikarze wskazywali na niedostatek informacji poprzedzających te działania. Takie same zarzuty padały ze strony zainteresowanych pracowników służby zdrowia oraz administracji państwowej. Podczas sondażu CBOS zadano respondentom pytanie, „o której z reform chciałby pan(-i) uzyskać więcej informacji” ${ }^{\prime 18}$. Otrzymano nastę-

14 Określenie charakteru „Tygodnika AWS”, jak i pozostałych prezentowanych

pism, za: Prasa, radio, telewizja, Warszawa 1999.

15 Media $w$ Polsce $w$ XX wieku, Poznań 1999.

16 Badanie OBOP, Aktualne problemy $i$ wydarzenia, 17-22 czerwca 1998.

17 www.kprm.gov.pl.

18 Badanie CBOS, Aktualne problemy $i$ wydarzenia, 17-22 września 1998. Badanie przeprowadzono po rozpoczęciu kampanii informacyjnej poprzedzającej reformy. 
pujące odpowiedzi: reforma ubezpieczeń społecznych - 33\%, reforma służby zdrowia $-24 \%$, reforma szkolnictwa - $12 \%$, reforma administracyjna $-4 \%$, wszystkie reformy $-20 \%$. Wskazuje to na niedostateczną, pomimo podjętych działań, politykę informacyjną rządu ${ }^{19}$.

Trzeba przypomnieć, że inicjatorem zjednoczenia podmiotów politycznych w federację Akcji Wyborczej Solidarność był Niezależny Samorządny Związek Zawodowy „Solidarność”. Spotkanie założycielskie odbyło się 8 czerwca 1996 roku. Uczestniczyło w nim, oprócz NSZZ „Solidarność", ponad dwadzieścia podmiotów politycznych i organizacji, między innymi Instytut Lecha Wałęsy, Porozumienie Centrum, Zjednoczenie Chrześcijańsko-Narodowe, Ruch dla Rzeczypospolitej, Konfederacja Polski Niepodległej, Ruch STU, Solidarni w Wyborach, Nowa Polska, Obóz Patriotyczny itp. (AWS tworzyło aż 37 partii politycznych).

Należy wyjaśnić kwestię odróżnienia Akcji Wyborczej Solidarność od Ruchu Społecznego „Akcja Wyborcza Solidarność”. Zamierzeniem Mariana Krzaklewskiego było, aby AWS pozostała luźnym blokiem wyborczym, podczas gdy niezależnie miała być budowana od podstaw partia polityczna (RS AWS $)^{20}$. Z czasem RS AWS stał się najsilniejszą partią AWS, obok Stronnictwa Konserwatywno-Ludowego i Zjednoczenia Chrześcijańsko-Narodowego. Dodatkowe komplikacje wprowadził plan Krzaklewskiego, zgodnie z którym kilkadziesiąt stowarzyszeń miało przenieść się z AWS do RS AWS ${ }^{21}$. Tymczasowo wstrzymano akces partii politycznych. Ugrupowanie miało się początkowo nazywać Akcja Wyborcza NSZZ „Solidarność”, ale zrezygnowano z członu NSZZ, aby nie utrudniać partiom politycznym wstępowania do AWS ${ }^{22}$. Autorem nazwy była profesor socjologii Jadwiga Staniszkis ${ }^{23}$.

Jak wielokrotnie podkreślano, przyczyną podjęcia działań politycznych przez związek zawodowy „Solidarność” była potrzeba zjednoczenia prawicowych ugrupowań, głównie o solidarnościowym rodowodzie, w celu wystawienia wspólnej, silnej reprezentacji w wyborach parlamentarnych w 1997 i w wyborach samorządowych w 1998 roku. Dwa silne ugrupowania wchodzące w skład Akcji Wyborczej Solidarność - Stron-

19 www.aws.org.pl (strona internetowa wygaszona po rozpadzie AWS).

20 Czas na akcję: Marian Krzaklewski w rozmowie z Maciejem Lętowskim i Piotrem Zaremba, Warszawa 1997, s. 227.

21 M. Janicki, Ruch Krzaklewskiego, „Polityka” 1997, nr 47.

22 Czas na akcję..., s. 220.

23 Ibidem. 
nictwo Konserwatywno-Ludowe i Zjednoczenie Chrześcijańsko-Narodowe - wywodzą się z Ruchu Młodej Polski ${ }^{24}$. Z czasem dzięki przyjęciu formuły otwartości, skład Akcji Wyborczej Solidarność, powiększył się do blisko 40 podmiotów politycznych i organizacji. W „Karcie AWS” określono założenia programowe ugrupowania ${ }^{25}$.

Nie zaproszono Ruchu Odbudowy Polski i Unii Wolności, pomimo solidarnościowych korzeni obydwu ugrupowań ${ }^{26}$. Umawiające się strony nie przewidywały istnienia wspólnej listy wyborczej Akcji Wyborczej Solidarność i Unii Wolności - ta reguła nie miała obowiązywać przy wyborach do Senatu. Osobne porozumienia miały być zawarte z Ruchem Odbudowy Polski ${ }^{27}$. W listopadzie 1997 roku zawarto umowę koalicyjną z Unią Wolności, co przypieczętowało powstanie centroprawicowej koalicji $^{28}$.

Inicjatywa „Solidarności”29, mająca na celu zjednoczenie prawicy i centroprawicy, nie była pierwszą taką próbą. W 1994 roku, przed wyborami samorządowymi, powstały - niezależnie od siebie - Przymierze dla Polski i Porozumienie 11 Listopada. W tym samym roku ukonstytuował się Sekretariat Ugrupowań Centroprawicowych ${ }^{30}$. Przykładem nieudanego przedsięwzięcia politycznego był Konwent Świętej Katarzyny - koalicja ugrupowań prawicowych, powołana w 1994 roku w celu wystawienia wspólnego kandydata w wyborach prezydenckich. Nazwa wywodziła się od miejsca spotkania - plebanii warszawskiego kościoła pw. Świętej Katarzyny. Cel nie został osiągnięty, w związku z tym Konwent został rozwiązany w $1995 \mathrm{roku}^{31}$.

24 Ruch Młodej Polski powstał w 1979 r. w środowisku gdańskiego duszpasterstwa akademickiego. Celem RMP była m.in. walka o przestrzeganie praw człowieka w PRL. Działaczami RMP byli m.in.: Aleksander Hall, Marek Jurek, Jacek Bartyzel, Tomasz Wołek, Józef Rybicki. Zob. P. Zaremba, Młodopolacy, Wrocław 2000.

25 Por. też: Aneks I, Założenia programowe Akcji Wyborczej Solidarność.

26 Zob. M. D. Zdort, Akcji Wyborczej Solidarność z prawica, „Rzeczpospolita”, 6.10.1996.

27 Ibidem.

28 W wyborach parlamentarnych AWS uzyskała 202 mandaty, UW - 60. Akcji Wyborczej Solidarność przypadło 17 tek ministerialnych, Unii Wolności - 6. Zob. J. Muszyński, Marketing polityczny, Warszawa 1999, s. 114.

29 Ibidem.

30 Leksykon politologii, Wrocław 1999, s. 751.

31 Ibidem. 
Akcja Wyborcza Solidarność powstała z inicjatywy związku zawodowego „Solidarność” i została zarejestrowana jako partia polityczna. AWS miała w przyszłości - jak zakładano - stopniowo zastąpić związek zawodowy na scenie politycznej kraju ${ }^{32}$. Nie bez znaczenia, uwzględniając historyczne korzenie „Solidarności”, był fakt, że na siedzibę Akcji Wyborczej Solidarność wybrano Gdańsk ${ }^{33}$.

Na liście podmiotów uczestniczących w Akcji Wyborczej Solidarność znalazły się związki zawodowe, organizacje młodzieżowe, partie polityczne, fundacje. Powstał podmiot polityczny o silnym wewnętrznym zróżnicowaniu, który J. Muszyński określił „dziwnym konglomeratem różnej jakości i ilości sił pragnących odsunąć lewicę od władzy, lecz sa-

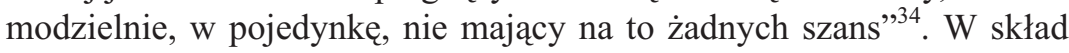
AWS weszły ugrupowania, które - pomimo wspólnego mianownika centroprawicowego - różniły się poglądami ekonomicznymi, społecznymi i politycznymi ${ }^{35}$. Akcja Wyborcza Solidarność została zarejestrowana jako partia polityczna. W wyborach parlamentarnych 2001 roku występowała jako koalicja wyborcza ${ }^{36}$. AWS stanowiła konglomerat ${ }^{37}$ ugrupowań $^{3}$ politycznych o różnej proweniencji (związki zawodowe, partie prawicowo-liberalne, chrześcijańsko-narodowe, konserwatywne), zawiązany dla doraźnego celu, jakim było utworzenie politycznej przeciwwagi dla postkomunistycznego Sojuszu Lewicy Demokratycznej i wygranie wyborów parlamentarnych. W skład AWS weszło ugrupowanie RS AWS, często mylone przez publicystów z AWS. Właśnie Ruch Społeczny AWS w naturalny sposób stał się rdzeniem Akcji Wyborczej Solidarnośćc ${ }^{38}$.

W styczniu 1999 roku odbyło się Pierwsze Zgromadzenie Krajowe Ruchu Społecznego AWS; przyjęto wtedy Deklarację Ideowo-Progra-

32 Historia Ruchu Społecznego AWS, www.rsaws.pl, stan na dzień 6.06.2002.

33 Potwierdzenie Gdańska jako siedziby partii znalazło się w rozdziale I, § II Statutu RS AWS.

34 J. Muszyński, Marketing..., s. 124. Marek Jurek widzi w AWS syntezę ruchu solidarnościowego, prawicowo-liberalnego, narodowo-katolickiego. Zob. O realnych marzeniach, straconych $i$ wykorzystanych szansach, „Kwartalnik Konserwatywny” 2001, nr 7.

35 Ibidem.

36 Klauzulę zaporową dla koalicji wyborczych w Polsce stanowi 8-procentowy próg poparcia.

Człon „Ruch” w pełnej statutowej nazwie partii - Ruch Społeczny AWS wskazuje na szeroko rozumianą koalicję polityczną.

38 Por. też: Aneks II, Deklaracja Ideowo-Programowa Ruchu Społecznego AWS. 
mową, ustalono kształt struktur partii. W Deklaracji Ideowo-Programowej znalazły się zapisy o solidarnościowej genezie RS AWS, deklaracja przyjęcia katolickiej nauki społecznej i chrześcijańskiego światopoglądu w ogóle, jako bazy aksjologicznej ugrupowania. Wskazano na zasady pomocniczości, współodpowiedzialności i współuczestnictwa jako właściwe dla tworzonego przez AWS modelu państwa. Powołanie się na wartości chrześcijańskie pojawiło się również w preambule statutu partii ${ }^{39}$. Sformułowana deklaracja ideowa wchodzi w skład myśli programowej partii, jest fundamentem programu politycznego. Założenia ideologiczne rzadziej też ulegają zmianie ${ }^{40}$.

W statucie RS AWS znalazły się odniesienia do genezy większości ugrupowań wchodzących w skład koalicji. W rozdziale II, paragraf 5, znalazł się zapis o współpracy ze związkiem zawodowym „Solidarność” na płaszczyźnie spraw publicznych. W preambułę wpisano zwycięstwo „Solidarności" lat 80, obok takich wydarzeń, jak chrzest Polski, uchwalenie Konstytucji 3 Maja, odzyskanie niepodległości w 1918 roku. Charakterystyczny jest również zapis (rozdział I, paragraf 4) nakładający na osobę przystępującą do RS AWS wymóg zadeklarowania, że nie współpracował z tajnymi służbami PRL.

Statut określa sposób organizacji wewnętrznej partii. Najwyższym organem władzy w RS AWS ustanowiono Zgromadzenie Krajowe, obradujące co najmniej dwa razy w ciągu kadencji. W rozdziale VI, paragraf 50, wymieniono uprawnienia Zgromadzenia Krajowego. Należy do nich m.in. wybór przewodniczącego RS AWS i Rady Politycznej ${ }^{41}$ oraz wybór członków do innych organów (Rada Polityczna, Komisja Rewizyjna, Sąd Koleżeński). Zgromadzenie Krajowe uchwala regulaminy poszczególnych organów RS AWS, deklarację programową partii i inne uchwały. Zgromadzenie Krajowe ${ }^{42}$ jest organem kolegialnym, w skład którego wchodzą: Przewodniczący RS AWS, delegaci zgromadzeń regionalnych, przewodniczący regionów i sekcji tematycznych, Przewodniczący Rady

39 Zapisano, że członkowie AWS chcą kształtować pomyślną przyszłość kraju w oparciu o wartości chrześcijańskie. Nawiązano też do tradycji chrztu Polski. Por. Preambuta statutu RS AWS, www.rsaws.pl.

40 Por. W. Hładkiewicz, Partie polityczne, w: Wiedza o państwie, cz. II, Zielona Góra 1993.

41 Delegaci pierwszego Zgromadzenia Krajowego (1999 r.) uchwalili przyznanie Marianowi Krzaklewskiemu tytułu Honorowego Przewodniczącego RS AWS.

42 III Zgromadzenie Krajowe zwołano w październiku 2001 r. w celu przeanalizowania klęski wyborczej poniesionej w wyborach parlamentarnych. 
Politycznej, Sekretarz Generalny, pozostali członkowie Zarządu Krajowego, przewodniczący Komisji Rewizyjnej, Prezes Sądu Koleżeńskiego, a także parlamentarzyści i ministrowie wywodzący się z AWS wraz z premierem $^{43}$. Można stwierdzić pewne analogie między pozycją i uprawnieniami Zgromadzenia Krajowego RS AWS a najwyższym organem NSZZ „Solidarność" - Krajowym Zjazdem Delegatów, który wybiera przewodniczącego NSZZ i członków Komisji Krajowej. Wskazuje to na wykorzystanie pewnych rozwiązań związkowych w odniesieniu do struktur Ruchu Społecznego AWS.

Pomimo tych wszystkich sprzeczności wewnątrz Akcji Wyborczej Solidarność, podjęła ona trud przeprowadzenia reform ustrojowych. Jedną z pierwszych reform była zmiana systemu ubezpieczeń społecznych ${ }^{44}$, który był dotąd nieefektywny i nadmiernie obciążał budżet państwa. Decyzję o przeprowadzeniu reformy podjęto pod wpływem niekorzystnych tendencji demograficznych ${ }^{45}$. W wyniku reformy powołano trzy filary ubezpieczeń: pierwszy z nich stanowi zreformowany Zakład Ubezpieczeń Społecznych, drugi to Otwarte Fundusze Emerytalne (OFE) oraz Powszechne Towarzystwa Emerytalne (PTE), zaś w skład trzeciego filaru weszły wszelkie nieobligatoryjne formy oszczędzania ${ }^{46}$. Ta reforma spotkała się z przychylnym odbiorem społecznym. Najwięcej respondentów, bo $21 \%$, wyraziło przekonanie, że zyska na tej reformie - dla porównania: $12 \%$ wskazało na reformę oświaty; $10 \%$ na reformę służby zdrowia; $9 \%$ na reformę samorządowo-administracyjną ${ }^{47}$. Wynikało to ze wspomnianych wad dotychczasowego systemu emerytalnego, jak i z tego, że do upowszechnienia idei tej reformy zatrudniono profesjonalną agencję zajmująca się promocją wizerunku ${ }^{48}$. Pozytywny odbiór reformy został zakłócony przez skojarzenie jej założeń z nierzetelną kampanią reklamową niektórych Powszechnych Towarzystw Emerytalnych. Nie dość jasno przedstawiono także kwestie związane $\mathrm{z}$ wyborem między drugim i trzecim filarem ${ }^{49}$.

43 Liczebność wybieralnych władz AWS dla poszczególnych organów określono też w Ordynacji Wyborczej RS AWS.

44 Zob. J. Koral, Główne założenia reform, w: Cztery reformy: od koncepcji do realizacji, pod red. L. Kolarskiej-Bobińskiej.

45 Ibidem.

46 Ibidem.

47 Sondaż OBOP, „Polacy o reformach społecznych”, wrzesień 1999.

48 Zob. M. Żukowski, Reforma emerytalna po roku, w: Cztery reformy..., s. 101.

49 A. Dryszel, Lekarstwo gorzkie, ale konieczne, ,Przegląd Tygodniowy” 1999, nr 4. 
Przesłanką przeprowadzenia reformy systemu opieki zdrowotnej było odpolitycznienie kwestii przyznawania służbie zdrowia środków z budżetu i powiązanie wysokości tych środków z wysokością zarobków społeczeństwa $^{50}$.

W wyniku zmian powstało 16 regionalnych kas chorych (na poziomie województw) oraz jedna branżowa (wojsko, policja, kolej) ${ }^{51}$. Cele tych zmian nie zostały, przynajmniej przed reformą, ujęte w żadnym formalnym dokumencie, stąd należy o nich wnioskować na podstawie przyjętej w 1994 roku ,Strategii dla zdrowia i przekształceń podstawowej opieki zdrowotnej". W dokumencie tym wymienia się następujące cele: poprawę stanu zdrowia społeczeństwa, zapewnienie powszechności dostępu do świadczeń zdrowotnych, z zachowaniem równych praw co do zakresu i jakości opieki dla wszystkich uprawnionych. Planowano również zwiększenie skuteczności systemu opieki zdrowotnej i poprawę jakości świadczeń oraz zapewnienie stabilnych źródeł finansowania lecznictwa ${ }^{52}$.

Nawet w przychylnym koalicji rządzącej „Tygodniku Solidarność” dostrzegano niepowodzenia we wprowadzaniu w życie reformy systemu opieki zdrowotnej ${ }^{53}$. Reformę odbierano jako źle zorganizowaną; ponadto wprowadzoną w zbyt krótkim czasie. Krytykowano utratę znacznych środków finansowych w trakcie zmian, jak i utworzenie się zbiurokratyzowanych struktur. Wprowadzaniu reformy towarzyszyły, pojawiające się na terenie całego kraju, utrudnienia w świadczeniu podstawowych usług zdrowotnych. Dziennikarka „Tygodnika Solidarność” użyła określenia „horror" wobec takiej sytuacji ${ }^{54}$.

Dla prasy sprzyjającej koalicji rządowej charakterystyczne jest szukanie przyczyn niepowodzenia reform w czynnikach zewnętrznych, obiektywnych. Za takie uważa się przyzwyczajenie wielu ludzi do starego, pochodzącego jeszcze z czasów PRL, systemu opieki zdrowotnej ${ }^{55}$. Winy szukano również po stronie współkoalicjanta - Unii Wolności; posłowie

50 Por. E. Cichocka, Główne założenia reform, w: Cztery reformy..., s. 141.

51 Ibidem, s. 143.

52 Zob. C. Włodarczyk, Cele reformy opieki zdrowotnej, w: Cztery reformy..., s. 147 .

53 J. Żyżyński, Kryzys zdrowia choroba koalicji, „Tygodnik Solidarność” 1999, nr 4.

54 A. Dołowska, Nie tak miało być, „Tygodnik Solidarność” 1999, nr 6; zob. też: Reforma w strajku - wywiad z Anną Knysok, ,Tygodnik Solidarność” 1999, nr 9.

55 Zob. E. Aronson, Człowiek istota społeczna, Warszawa 1998. 
tej partii mieli nie zgodzić się na niektóre zapisy ustawy, nie pozwalając $\mathrm{w}$ ten sposób na pełne przeprowadzenie reformy.

W odmienny sposób przedstawiana była reforma systemu opieki zdrowotnej w lewicowej „Trybunie”. Krytykowano „bałagan, niekompetencję, czystkę kadrową". Generalnie, określenie „bałagan” pojawia się bardzo często w artykułach „Trybuny” dotyczących wszystkich reform, nie tylko reformy służby zdrowia. Przykładem mogą być tytuły artyku-

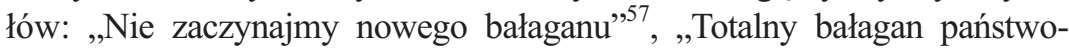
wy" ${ }^{\text {, }}$, „Dawno już nie było takiego bałaganu" ${ }^{\text {,59 }}$. Interesującym zabiegiem socjotechnicznym było to, że niektóre artykuły krytykujące służbę zdrowia pisali doktorzy medycyny: Mariusz Łapiński ${ }^{60}$ oraz Jerzy Borowicz tytuł doktora medycyny wskazuje na fachowca, a więc znacznie podnosi wiarygodność autora w oczach odbiorców.

Natychmiast po wprowadzeniu w życie reformy służby zdrowia, „Gazeta Wyborcza" rozpoczęła cykl publikacji o charakterze poradnikowym, np. seria artykułów: „Jak przeżyć reformę zdrowia?” E. Cichockiej ${ }^{61}$ czy „Jak się leczyć w bałaganie?” tej samej autorki ${ }^{62}$. Dziennik „Życie”, ideologicznie związany z obozem rządzącym, nie negował potrzeby reform ani ich przebiegu. Podobnie, jak w „Gazecie Wyborczej”, pojawiły się w „Życiu” specjalne dodatki, pod wspólnym tytułem „Nowa Polska”; każdy dodatek poświęcony został jednej reformie. We wstępie do dodatku „Reforma opieki zdrowotnej” przedstawiono stosunek redakcji do zmian w służbie zdrowia: „Reforma to konieczność, choćby ze względu na kolejki do lekarzy, opryskliwe pielęgniarki, niedbali lekarze, brudne sale w szpitalach, łapówki, wielomiesięczne czekanie na zabieg czy badanie"63.

Reforma terytorialna Polski odbiła się największym echem w środkach społecznego przekazu. Było to konsekwencją ogólnospołecznej debaty, powstawały różne stowarzyszenia, komitety i inne lokalne inicja-

56 M. Łapiński, Stan zapaści, „Trybuna” 1999, nr 4.

57 K. Krauss, Nie zaczynajmy nowego bałaganu, „Trybuna” 1999, nr 18.

58 K. Koźniewski, Totalny bałagan państwowy, „Trybuna” 1999, nr 39.

59 J. Borowicz, Dawno już nie było takiego bałaganu, ,Trybuna” 1999, nr 7.

60 Autor był doradcą do spraw zdrowia Klubu Parlamentarnego Sojuszu Lewicy Demokratycznej.

${ }_{61}$ Zob. „Gazeta Wyborcza”, numery z lutego i marca 1999 roku.

62 Zob. m.in. codzienne wydanie „Gazety Wyborczej” w dniach 13.01-1.02.1999.

63 Wstęp do dodatku „Nowa Polska. Reforma opieki zdrowotnej” do „Życia”, 6.01.1999. 
tywy, których celem była obrona danego województwa przed likwidacją czy też obrona miasta przed utratą statusu miasta wojewódzkiego bądź powiatowego. Do tego ruchu należy też zaliczyć wszelkie lokalne referenda, zorganizowane w celu wypowiedzenia się mieszkańców danej społeczności co do przynależności terytorialnej. Temat nowego podziału administracyjnego kraju wzbudził wiele emocji, próbowano udowodnić, że likwidacja niektórych województw jest wynikiem „niepoprawnie” oddanych głosów w wyborach pralamentarnych.

Konsekwencją przyjęcia nowego podziału administracyjnego kraju stały się poważne zmiany mapy administracyjnej Polski. Utworzono 16 nowych województw, w miejsce poprzednich 49. W ramach dekoncentracji władzy część kompetencji ministerialnych przekazano wojewodom, a niektóre kompetencje wojewodów przekazano samorządowi terytorialnemu. Województwa nabrały statusu rządowo-samorządowego, to znaczy miały zachować status przedstawiciela rządu w terenie, niemniej z charakterem regionalnej współpracy samorządowej ${ }^{64}$.

Elementami trójszczeblowego podziału administracyjnego kraju zostały więc: województwo, powiat i gmina. Powiaty i gminy nie otrzymały uprawnień nadzorczych i nadrzędnych, wobec gmin trójszczeblowy podział nie ma więc charakteru hierarchicznej zależności. Oprócz 16 województw, powołano 308 powiatów ziemskich, 65 miastom przyznano prawa powiatu grodzkiego. Poza pakietem nowych ustaw przeprowadzono zmiany w ponad stu ustawach szczegółowych ${ }^{65}$.

Należy zaznaczyć, że trójstopniowy podział administracji państwowej nie był celem samym w sobie, co umknęło w toku publicznej debaty o zasadności takiego podziału. Celem reformy było utworzenie ram dla podstawowych zadań władzy publicznej: administrowania, zarządzania zmianami, usług publicznych ${ }^{66}$. Wynikało to z koncepcji decentralizacji państwa, umocowanej prawnie w artykułach 15 i 16 Konstytucji, jak i w przyjętych przez Polskę aktach prawa europejskiego: Europejskiej Karcie Samorządu Regionalnego i Europejskiej Karcie Samorządu Lokalnego.

Niezadowolenie społeczne z reformy samorządowej nie było tak wysokie, jeśli zestawić je z oceną pozostałych reform. Negatywnie oceniło tę

64 Samorzqd terytorialny i administracja rzqdowa. Gmina, powiat, województwo, pod red. G. Rydlewskiego, Warszawa 1999.

65 Zob. Samorzad terytorialny...

66 Zob. J. Płoskonka, Główne założenia reform, w: Cztery reformy..., s. 12. 
reformę 52\% ankietowanych - tylko reformę systemu ubezpieczeń emerytalno-rentowych oceniono lepiej - tam 50\% ankietowanych wyrażało niezadowolenie. $48 \%$ pytanych wyraziło przekonanie, że reforma samorządowa nie przyniesie zysków ani strat, 7\% uznało, że ludzie zyskają na reformie ${ }^{67}$. To wysokie, w porównaniu z pozostałymi posunięciami rządu, poparcie znalazło duży oddźwięk w prasie.

W publikacjach „Trybuny”, podobnie jak w przypadku pozostałych reform, pisano o bałaganie i niekompetencji reformatorów ${ }^{68}$. Krytykowano finansowe niedociągnięcia związane $\mathrm{z}$ wdrażaniem reformy - niedofinansowanie powiatów, jak i placówek kulturalnych, oświatowych oraz infrastruktury $^{69}$; mówiono też o zbyt wysokich kosztach samej reformy ${ }^{70}$. Częstym zarzutem była „czystka kadrowa”, wprowadzanie na nowo utworzone w administracji stanowiska ludzi związanych z rządzącą koalicją $^{71}$. Przykładem typowej maniery pisania o reformie jest artykuł Z. Krzywickiego pod wymownym tytułem AWS niszczy samorzqdność, nadtytuł: Czy bałagan byt zaplanowany? ${ }^{72}$.

Na pewne złagodzenie krytyki wobec reformy wskazuje artykuł K. Janika Madrze sprawować władzę ${ }^{73}$. Autor akcentuje fakt, że reforma wymusiła demokratyzację władzy, decentralizację, demokratyzację wewnątrz partii politycznych. To swoiste chwilowe zawieszenie krytyki wobec reformy samorządowej wynikało z przytoczonych przez autora danych - Sojusz Lewicy Demokratycznej współrządził w 181 powiatach, czyli w większości. Ten sam artykuł zawiera krytykę reformy służby zdrowia i oświaty ${ }^{74}$.

Kojarzona z koalicyjną Unią Wolności „Gazeta Wyborcza” nie kwestionowała potrzeby reform w ogóle, także samorządowej. Krytykowano jednak brak wyczerpujących i aktualnych informacji (zarzuty dziennikarzy „Gazety Wyborczej” dotyczyły również pozostałych reform, nie tylko

${ }^{67}$ Sondaż OBOP, listopad 1999.

${ }_{68}$ M. Lapiński, Dokad zmierza Polska, „Trybuna” 1999, nr 4.

69 M. Podlaski, Powiat na kredyt, „Trybuna” 1999, nr 7; idem, Petenci, „Trybuna” 1999, $\mathrm{nr} 4$.

70 J. Rolicki, Pytania do premiera, „Trybuna” 1999, nr 6.

71 Zob. m.in.: Inżynierowie nowego państwa, „Trybuna” 1999, nr 1; Z. Wąsik, Miało być normalnie, „Trybuna” 1999, nr 5.

72 Z. Krzywicki, AWS niszczy samorzqdność, „Trybuna” 1999, nr 13.

${ }^{73}$ K. Janik, Madrze sprawować władze, „Trybuna” 1999, nr 11.

74 Por. też: Z. Dąbrowska, J. Wyganowski, Zapaść powiatowa, „Trybuna” 1999, nr 47; Ciasno, brudno, byle jak, nadtytuł: Urzędy marszałkowskie jak reforma, „Trybuna" 1999, nr 43. 
zmian w administracji terenowej). „Informacyjnym gniotem” nazwał Bogdan Cichoń oficjalne materiały informacyjne o władzach powiatowych na Mazowszu ${ }^{75}$. Podobnie jak w prasie lewicowej, krytycznie oceniano obsadzanie urzędów zgodne z politycznymi preferencjami - ale publicystka Dominika Wielowieyska zwróciła uwagę na fakt, że jest to typowe nie tylko dla polityków AWS. Jako kontrargument wobec lewicowych oponentów reformy, dziennikarka wskazała na pozytywny aspekt zmian personalnych - dojście do stanowisk ludzi nowych, nie obciążonych ,rutyną z PRL",76.

Plan reformy systemu edukacji był przedstawiony wybranym przedstawicielom polskich uczelni w 1998 roku w formie „pomarańczowej książeczki" "77. W wyniku reformy nastąpiły istotne przeobrażenia systemu edukacji w Polsce. Utworzono sześcioklasową szkołę podstawową, wprowadzono trzyletnie gimnazjum, po którym uczeń ma prawo wybrać trzyletnie liceum profilowane lub dwuletnią szkołę zawodową. Po dwóch latach szkoły zawodowej dawano możliwość kontynuowania nauki w dwuletnim liceum uzupełniającym $\mathrm{z}$ maturą ${ }^{78}$. Wprowadzono nowe, budzące liczne kontrowersje, zasady zdawania egzaminu maturalnego - tymczasowo zostawiono możliwość wyboru nowego lub starego sposobu zdawania matury. W założeniu autorów reformy, zdany egzamin maturalny miał gwarantować wstęp na studia. Wprowadzono też nowe zasady finansowania - tzw. bon edukacyjny. Poszczególne stopnie szkolnictwa przekazano szczeblom samorządu: szkolnictwo podstawowe wraz z przedszkolami przekazano gminie; szkolnictwo ponadpodstawowe powierzono powiatom; szkolnictwo wyższe i policealne - województwom ${ }^{79}$.

Reforma systemu edukacji, obok reformy służby zdrowia, spotkała się na łamach prasy lewicowej z najsilniejszą krytyką ze strony środowiska związanego ze Związkiem Nauczycielstwa Polskiego (ZNP wszedł w skład federacji podmiotów tworzących Sojusz Lewicy Demokratycznej).

75 B. Cichoń, Dezinformacja na kredowym papierze, „Gazeta Wyborcza”, 11.01.1999.

76 D. Wielowieyska, Karuzela urzędnicza, „Gazeta Wyborcza”, 18.02.1999.

77 Zob. A. Paciorek, Siedem pól zmian, w: Cztery reformy..., s. 208.

78 Ibidem.

79 Por. Samorzad terytorialny... 
Dziennikarze „Trybuny” w krytyce skupili się na problemie transportu do szkół - chodziło o wprowadzenie „gimbusów” czyli specjalnych autobusów dowożących uczniów do szkół. Wskazywano na niedostateczne możliwości finansowania „gimbusów” ${ }^{\text {" }}$. Generalnie zarzucono reformatorom przeniesienie uprawnień, co do szkolnictwa na samorząd terytorialny, bez odpowiedniego zabezpieczenia finansowego ${ }^{81}$.

Podnoszono też zarzut doboru kadr według politycznego klucza, uzależnienie dyrektorów szkół od lokalnych układów politycznych poprzez konieczność starania się o środki finansowe z samorządu ${ }^{82}$. Temat możliwych zwolnień podjął Marcin Podlaski - artykuł ilustrowany wymownym kolażem: obok tytułu Nauczyciele na bruku? przedstawiono zdjęcie szkolnej tablicy z napisem: „Witaj reformo!" 83 .

Podobną formę przekazu propagandowego wybrano w „Przeglądzie Tygodniowym". Na pierwszej stronie gazety umieszczono fotomontaż przedstawiający ministra edukacji narodowej, Mirosława Handkego, a obok tablica szkolna z napisami stylizowanymi na wykonane kredą: „brak pieniędzy”, „chaos w podręcznikach”, ,protesty nauczycieli”, „gimnazja na niby”, „tylko 10 gimbusów”84. W tym samym numerze Iwona Konarska stwierdzała, że „dwie reformy oświaty, jedna na papierze”, „bo druga to rzeczywistość" ${ }^{\prime 85}$. W lewicowej prasie oficjalnym komunikatom rządowym często przeciwstawiano konkretne przypadki błędów popełnionych przy wdrażaniu reform. Autorka pisała: „Reforma Handkego to strzępy, chaos i koszty. I propaganda sukcesu, uparte twierdzenie, że jest świetnie" ${ }^{\prime 86}$. Reformatorom zarzucano brak środków finansowych na reformę, brak gimbusów, brak informacji ${ }^{87}$.

W prorządowej prasie, jako argument za reformą oświaty, przytoczono wyniki raportu $\mathrm{OECD}$, w którym zestawiono szkolnictwo polskie i innych krajów. Wyniki nie były korzystne dla polskiej oświaty: 3\% Polaków posiadło zdolność czytania z pełnym rozumieniem tekstów, aż $40 \%$ uznano

80 V. Baran, J. Wyganowski, Reforma w oświatę, „Trybuna” 1999, nr 6; E. Biela, Gimbusem do reformy, „Trybuna” 1999, nr 34.

${ }^{81}$ Zob.: V. Baran, J. Wyganowski, Reforma w oświatę...; S. Turowski, Szkolna szamotanina, „Trybuna” 1999, nr 11.

82 S. Turowski, Szkolna szamotanina..., ibidem.

83 M. Podlaski, Nauczyciele na bruku?, „Trybuna” 1999, nr 46.

84 I. Konarska, Handke do tablicy, „Przegląd Tygodniowy” 1999, nr 35

85 I. Konarska, Dwie reformy oświaty, „Przegląd Tygodniowy” 1999, nr 35.

86 A. Golimont, Handke w reformach, „Nie” 1999, nr 1.

87 M. Barańska, Z dziejów handkizmu, „Nie” 1999, nr 18. 
za funkcjonalnych analfabetów ${ }^{88}$. Do tych danych odwoływali się dziennikarze tygodnika „Wprost” i „Gazety Wyborczej”. Publicyści „Wprost” argumentowali, że reforma szkolnictwa była niezbędna ze względu na niedostateczny poziom dotychczasowej edukacji w Polsce ${ }^{89}$. W „Gazecie Wyborczej" ukazał się artykuł o charakterystycznym tytule Wiedza wieś omija $^{90}$.

W dodatku do prawicowego dziennika „Życie” sugerowano, że reforma oświaty stanowi próbę poprawy dotychczasowego stanu szkolnictwa: „Rok temu po wyborach parlamentarnych pojawił się pomysł, by naprawić wszystko za jednym zamachem" ". Działania rządu spotkały się z aprobatą „Życia”, pomimo świadomości niedostatecznej informacji ze strony rządu: „O tym, że polska szkoła potrzebuje reformy, przekonani są wszyscy. Tylko nie wszyscy są pewni, że trzeba zmienić wszystko w tak krótkim czasie. Tym bardziej, że nauczyciele niewiele o niej wiedzą. Miejmy nadzieję, że przez 9 miesięcy nauczą się, jak po nowemu uczyć nasze dzieci" ${ }^{\prime 92}$.

W katolickim „Naszym Dzienniku” stwierdzano potrzebę debaty nad treścią ideową reformy szkolnictwa ${ }^{93}$. Oświacie nadano szczególną rolę, ze względu na to, że dotyczy ona ,sfery intelektualno-wolitywnej rzesz młodych ludzi" "94. Publicyści dziennika, związanego ideologicznie z „Radiem Maryja”, szczególny nacisk położyli na kwestie ideologiczne wychowania w szkole. Autor sprzeciwił się „neutralizmowi światopoglądowemu”, wyrażając pogląd, że reforma może prowadzić do „zneutralizowania kulturowotwórczej roli Kościoła”, dlatego pozytywnie ocenił dawny model szkół przykościelnych ${ }^{95}$. Zagrożenie widziano w ,ścieżkach przedmiotowych", które mogłyby stać się narzędziem europejskiej edukacji regionalnej ${ }^{96}$. Chwalono jednocześnie możliwość wpływu na szkołę za pomocą bonu edukacyjnego, bo zapewniałby on możliwość wyboru szkoły oraz utrudniałby „,sączenie niepożądanej ideologii” w szkole ${ }^{97}$.

\footnotetext{
88 S. Janecki, J. Szczęsny, Szkoła oporu, „Wprost” 1999, nr 35.

${ }^{89}$ Ibidem.

90 W. Staszewski, Wiedza wieś omija, „Gazeta Wyborcza”, 13-14.02.1999.

91 Dodatek „Nowa Polska. Reforma Edukacji”, „Życie”, 7.01.1999.

92 Ibidem.

93 P. Korycki, Potrzebna debata, „Nasz Dziennik”, 18.03.1999.

94 P. Gontek, Polski pejzaż edukacyjny, „Nasz Dziennik”, 6.09.1999.

95 Ibidem.

96 Ibidem.

97 M. Wojciechowski, Bon, ale jaki?, „Nasz Dziennik”, 6.09.1999.
} 
Reasumując, dla potrzeb kontaktów z mediami nie wypracowano jednolitego, spójnego wizerunku Akcji Wyborczej Solidarność, utworzonego. Co więcej, istniała wobec AWS jakby „potrójna opozycja”. Po pierwsze opozycja parlamentarna, czyli Sojusz Lewicy Demokratycznej wraz z Unią Pracy (a i częściowo inne ugrupowania, np. PSL czy ROP). Po drugie - tarcia powstawały wewnątrz AWS, czego przykładem był projekt uwłaszczeniowy, autorstwa związanego z ruchem katolickim prof. Bieli, krytykowany nawet $\mathrm{w}$ środowisku AWS, czy głosowanie nad ustawą o dekomunizacji. Wreszcie, narastał konflikt na linii AWS-UW (np. sprawa uwłaszczenia; politycy radykalnej prawicy krytykowali ministra finansów Leszka Balcerowicza), co w efekcie doprowadziło do wystapienia Unii Wolności z koalicji. Dlatego federacja AWS nigdy nie wytworzyła wizerunku jednego, spójnego ugrupowania i była odbierana jako doraźna koalicja wyborcza.

Wynik badań, opartych na analizie treści prasy centralnej w odniesieniu do sposobu przedstawiania AWS, każe z pesymizmem oceniać skuteczność marketingu politycznego w Polsce. Nie wynika to bynajmniej ze słabości samej dyscypliny, ale ze sztywnych ram politycznych środków przekazu, gdzie dominuje kryterium „swój-obcy”, nie zaś skuteczność działań.

Należy zaznaczyć, że powstanie oraz funkcjonowanie AWS warte jest opracowania jako pierwsza tak spektakularna inicjatywa jednocząca ugrupowania prawicowe. W pełni uzasadnione jest stwierdzenie, że AWS była partią sukcesu, a zblokowana prawica uzyskała zwycięstwo w wyborach parlamentarnych. Praktyka pokazała, że politykom prawicy nie udało się wykorzystać walorów nowego ugrupowania. Problemem Akcji Wyborczej Solidarność stały się destruktywne tarcia wewnątrz partii (znamienne jest określenie AWS ,prawicową wieżą Babel" ${ }^{88}$ ), jak i niezdecydowanie przywództwa. Sukces AWS szybko został przesłonięty nieudolnością władz ugrupowania, brakowało także spójnej polityki. Pomimo wielkiej szansy, Akcja Wyborcza Solidarność nie stała się zjednoczonym ugrupowaniem polskiej prawicy. Podmioty tworzące AWS nie były w stanie utworzyć nowej jakościowo partii politycznej (AWS w przegranych wyborach parlamentarnych 2001 roku występowała jako koalicja wyborcza). Liderzy poszczególnych organizacji, wchodzących w skład

98 P. Siennicki, Świat bez Mariana.... 
AWS, nie zrezygnowali z własnych ambicji przywódczych. Miało to szczególne znaczenie pod koniec istnienia koalicji AWS-UW, kiedy następowała szybka erozja prawicowego bloku.

W obliczu niedoskonałej polityki informacyjnej rządu AWS-UW, można stwierdzić, że medialne poparcie dla tej koalicji na łamach gazet centrowych i prawicowych (od „Gazety Wyborczej” po „Nasz Dziennik”) powstało jako suma poparcia poszczególnych tytułów dla ugrupowań (np. „Gazeta Wyborcza” - Unia Wolności, „Nasz Dziennik” - Zjednoczenie Chrześcijańsko-Narodowe itp.), nie jako wynik działań marketingu politycznego. Pozostawia to problem dla przyszłych badań, na ile w polityce informacyjnej AWS wykorzystano i wyczerpano możliwości, jakie były dostępne w danym momencie.

\section{Summary}

Although the Solidarity Election Action (AWS) had been the first impressive attempt to unite right-wing groupings after 1989 which was effected in practice, it failed to develop a united, coherent image for the purpose of contacts with the media throughout the whole period it was in power. Reality showed that right-wing politicians failed to take advantage of the assets of the new grouping. Incompetence of its leaders and absence of a coherent policy quickly overshadowed the success of the Solidarity Election Action. As a consequence, Solidarity Election Action has wasted an enormous chance and failed to become a united group of the Polish right wing. Leaders of individual organizations composing the AWS did not give up their leaders' ambitions, which became particularly significant towards the end of the AWS-UW (Solidarity Election Action - Liberty Union) coalition, when the right-wing block was eroding rapidly. 